\title{
Rekam Medis Odontogram Sebagai Alat Identifikasi Dan Kepentingan Pembuktian Di Pengadilan
}

\author{
Trisnowahyuni, Agus Hadian Rahim dan Eddie Imanuel Doloksaribu \\ trisno.wahyuni@gmail.com \\ Magister Hukum Kesehatan \\ Universitas Katolik Soegijapranata Semarang
}

\begin{abstract}
ABSTRAK
Identifikasi melalui rekam medis odontogram bertujuan untuk memenuhi persyaratan sebagai tenaga professional dokter, dokter gigi ataupun tenaga kesehatan lainnya di dalam pembuatan rekam medis. Pelaksanaannya harus sesuai dengan peraturan yang telah ditetapkan, selain banyak manfaatnya rekam medis ini dapat dipakai sebagai alat bukti di pengadilan. Saat ini belum semua dokter gigi maupun perawat gigi di Indonesia melakukan pencatatan rekam medis odontogram secara benar. Masih belum adanya keseragaman dalam tata cara penulisan maupun pengistilahan yang digunakan dalam pencatatan rekam medis odontogram sehingga menimbulkan kesalahpahaman saat rekam medis tersebut dimanfaatkan dalam suatu proses hukum. Standar Operasi Prosedur mengenai rekam medis odontogram perlu diterapkan dan dilaksanakan pada setiap pelayanan kesehatan baik instansi pemerintah, swasta maupun pratik perseorangan dengan standar Nasional maupun Internasional secara manual, digital maupun secara elektronik.
\end{abstract}

Kata kunci : Odontogram, Data antemortem, Identifikasi, Alat bukti.

\section{PENDAHULUAN}

\section{A. LATAR BELAKANG PERMASALAHAN}

Salah satu unsur utama dalam sistem pelayanan kesehatan yang prima adalah tersedianya pelayanan medis oleh dokter dan dokter gigi dengan kualitasnya yang terpelihara sesuai dengan amanah Undang-Undang Nomor 29 Tahun 2004 tentang Praktik Kedokteran. Dalam penyelenggaraan praktik kedokteran, setiap dokter dan dokter gigi wajib mengacu pada standar, pedoman dan prosedur yang berlaku sehingga masyarakat mendapat pelayanan medis secara profesional dan aman. Sebagai salah satu fungsi pengaturan dalam Undang-Undang Praktik Kedokteran Tahun 2004 yang dimaksud adalah pengaturan tentang rekam medis yaitu pada Pasal 46 dan Pasal 47.

Permasalahan dan kendala utama pada pelaksanaan rekam medis adalah dokter dan dokter gigi tidak menyadari sepenuhnya manfaat dan kegunaan rekam medis, baik pada sarana pelayanan kesehatan maupun pada praktik perorangan, akibatnya rekam medis dibuat tidak lengkap, tidak jelas dan tidak tepat waktu. Saat ini telah ada pedoman rekam medis yang diterbitkan oleh Departemen Kesehatan RI, namun pedoman tersebut hanya mengatur rekam medis rumah sakit. Karena itu, diperlukan acuan rekam medis penyelenggaraan praktik kedokteran yang berkaitan dengan aspek hukum yang berlaku baik untuk rumah sakit negeri, swasta, khusus, puskesmas, perorangan dan pelayanan kesehatan lain.

Berkaitan dengan rekam medis tersebut peran dokter gigi cukup penting dalam pembuatan data berupa odontogram sebagai proses identifikasi. Oleh karena itu identifikasi seseorang yang merupakan data pribadi sangatlah diperlukan terutama gigi geligi yang melekat 
erat pada tulang rahang, tahan terhadap proses pembusukan, tahan terhadap panas sampai 900 derajat Celcius, tahan terhadap asam, tahan terhadap abrasi maupun atrisi, nilai individualistisnya tinggi, Identifikasi melalui gigi geligi ini adalah proses menetapkan karakteristik unik gigi seorang individu dengan cara membandingkan data paskakematian dengan data prakematian.

Setiap orang mempunyai identitas untuk membedakannya dari orang lain. Identitas ini mempunyai aspek hukum. Antisipasi terhadap hal-hal tersebut yang paling utama, sederhana, dan dapat segera dilaksanakan adalah dengan cara membenahi atau membuat Rekam Medis Gigi dalam hal ini odontogram yang baik, lengkap, seragam, serta mudah dimengerti, baik oleh kalangan medis, paramedis, penegak hukum, maupun orang awam, dengan memakai standar yang berlaku universal (nasional dan internasional). Dengan perkembangan ilmu pengetahuan dan teknologi, data gigi selain dibuat secara manual pada kartu pasien dapat juga dibuat secara digital (pada komputer) maupun secara elektronik dengan biaya yang secara ekonomis terjangkau.

Rekam medis gigi secara keseluruhan merupakan data tertulis pada kartu atau komputer yang berisi informasi lengkap dan akurat tentang identitas pasien, diagnosa, proses perawatan/pengobatan, tindakan medis kedokteran gigi serta dokumentasi hasil pemeriksaan yang merupakan alat bukti yang sah menurut hukum. ${ }^{1}$

\section{B. PERUMUSAN MASALAH}

a. Bagaimana dokter gigi dapat menerapkan rekam medis odontogram dengan benar dan baik dikaitkan dengan kewajibannya yang telah ditentukan sebagai peraturan yang harus dijalankan?

b. Bagaimana penggunaan odontogram sebagai alat bukti Identifikasi di Pengadilan ?

c. Bagaimana ketentuan peraturan rekam medis odontogram elektronik?

\section{TUJUAN PENULISAN TESIS}

Tujuan dan penulisan tesis ini adalah :

a. Untuk mensosialisasikan rekam medis odontogram ke seluruh masyarakat Indonesia sebaiknya diwajibkan setiap individu mempunyai catatan data odontogram gigi sebagai identifikasi jati diri.

b. Untuk mengetahui apakah data odontogram yang telah dimiliki seseorang mempunyai kepentingan dalam menjalankan tugasnya.

c. Untuk mengetahui kemajuan data odontogram elektronik maupun digital.

\section{MANFAAT}

Manfaat dari penulisan tesis ini adalah sebagai berikut :

a. Secara teoritis, penulisan tesis ini diharapkan dapat memberi sumbangan pemikiran bagi berbagai pihak, juga sangat diperlukan sebagai alat pembuktian di pengadilan.

b. Secara praktis mengingatkan kepentingan perseorangan, institusi rumah sakit atau praktek pribadi maupun permasalahan nasional dan internasional karena merupakan suatu identitas diri.

\section{E. POLA PEMIKIRAN}

Pola pemikiran berisi konsep-konsep yang dikaji dalam pola pemikiran sebagai acuan dalam penulisan yang akan dilakukan, termasuk variabel-variabelnya.

1 Drg. Shindhy R. Malingkas, DFM Dental Charting (In Use to DVI Interpol Post Mortem form) BIDDOKPOL PUSDOKKES POLRI 


\section{F. METODOLOGI PENELITIAN}

a. Spesifikasi Penelitian

Menurut Soetandyo Wignjosoebroto, penelitian hukum normatif atau doktrinal adalah penelitian-penelitian hukum yang dikonsepkan dan dikembangkan atas dasar doktrin yang dianut oleh pengkonsep dan/atau pengembangnya. ${ }^{2}$

Yang dimaksud dengan deskriptif analitis adalah mencari sebab akibat dari suatu hal dan menguraikannya secara konsisten dan sistematis serta logis ${ }^{3}$.

b. Metode Pendekatan

Metode pendekatan yang dipergunakan dalam penelitian ini adalah metode pendekatan yuridis normatif 4 .

c. Jenis Data

Data yang dipergunakan dalam penelitian ini, yaitu berdasarkan klasifikasi dari sifat dan sumbernya.

1. Berdasarkan sifatnya (ciri-ciri khusus), data dapat diklasifikasikan menjadi data kualitaif ${ }^{5}$ dan data kuantitatif.

2. Sedangkan berdasarkan sumbernya. Data primer (field research) ${ }^{6}$ dan data sekunder (library research) ${ }^{7}$.

3. Dalam penelitian hukum, data sekunder tersebut meliputi :

Bahan hukum primer, bahan hukum sekunder dan bahan hukum tertier

4. Metode Pengumpulan Data adalah data sekunder yang bersifat kualitatif.

5. Metode Analisis Data adalah metode kualitatif normatif.

\section{G. SISTEMATIKA PENULISAN}

Dalam penulisan tesis ini sistematika yang akan digunakan adalah sebagai berikut:

BAB I. Pendahuluan, terdiri dari latar belakang permasalahan, perumusan masalah dan manfaat dari penulisan tesis.

BAB II. Studi Pustaka memuat teori-teori yang berkaitan dengan rekam medis dan catatan gigi geligi (dental record) berfokus pada data odontogram berisikan data antemortem gigi geligi yang digunakan sebagai sarana identifikasi yang berkepentingan dalam pembuktian di Pengadilan.

BAB III. Pembahasan memuat tulisan yang mencari jawaban dari permasalahan yang ada yang didukung dengan dasar teori yang ada. Membahas tentang rekam medis dan data odontogram dalam kaitannya dengan identifikasi.

BAB IV. Penutup, merupakan kesimpulan serta saran-saran kepada pihak terkait.

2 Soetandyo Wignjosoebroto, 2002, Hukum (Paradigma Metode dan Dinamika Masalahnya) Editor: Ifdhal Kasim et.aL, Elsam dan Huma, Jakarta, hal. 147-160.

3 Moh. Nazir, 1985, Metode Penelitian, Ghalia Indonesia, Jakarta, hIm. 63, 72, 405, 406 \& 427; Lihat pula Human Hadikusuma, 1995, Metode Pembuatan Kertas Kerja atau Skri psi Ilmu Hukum, Mandar Maju, Bandung, hal. 98

4 Soerjono Soekanto \& Sn Mamudji, 2001, Penelitian Hukum Normatif (Suatu Tinjauan Singkat), Rajawaii Pers, Jakarta, hal. 13-14.

5 Taliziduhu Ndraha, Research, 1985, (Teori Metodologi Administrasi), Bina Aksara, Jakarta, hal. 60-61;

6 H. Hadan Nawawi \& H.M. Martm Hadan, 1995, Instrumen Peneiltian Bidang Sosial, Gadjah Mada Unversity Press, Yogyakarta, hal. 28-29

7 Ibid hal. 40-42 


\section{TINJAUAN PUSTAKA}

Pada bab tinjauan studi pustaka ini akan dikupas dan diulas mengenai rekam medis (medical record) yang didalamnya memuat catatan data odontogram dari berbagai segi sudut pandang, baik itu mengenai pengertian dan difinisi rekam medis serta pentingnya catatan odontogram, aspek hukumnya, kegunaan dan manfaat. Diuraikan pula bagaimana mensosialisasikan rekam medis odontogram bagi seluruh dokter gigi agar mewajibkan setiap individu yang datang berobat atau melakukan pemeriksaan berkala mempunyai catatan data odontogram sebagai identifikasi jati diri melalui catatan odontogram dengan standar internasional

\section{A. REKAM MEDIS}

a. Difinisi Rekam Medis

Sunny Ummul Firdaus menuliskan di dalam Penjelasan Pasal 46 ayat (1) UndangUndang Kedokteran Tahun 2004 Rekam Medis adalah berkas yang berisi catatan dan dokumen mengenai identitas pasien, hasil pemeriksaan, pengobatan, tindakan dan pelayanan lainnya yang diterima pasien pada sarana kesehatan, baik rawat jalan maupun rawat inap. Ini ditegaskan juga pada Pasal 1 Permenkes RI Nomor 269/Menkes/Per/III/2008 bahwa Rekam Medis adalah berkas yang berisikan catatan dan dokumen tentang identitas pasien, pemeriksaan, pengobatan, tindakan dan pelayanan lain yang telah diberikan pada pasien. Sedangkan Edna K Huffman menjelaskan Rekam Medis adalah berkas yang menyatakan siapa, apa, mengapa, dimana dan bagaimana pelayanan yang diperoleh seorang pasien selama dirawat atau menjalani pengobatan, kemudian IDI juga menuliskan sebagai rekaman dalam bentuk tulisan dan gambaran aktifitas pelayanan yang diberikan oleh pemberi pelayanan medis/kesehatan kepada seorang pasien ${ }^{8}$.

Mengenai tenaga kesehatannya juga tercantum dalam Undang-Undang Nomor 36 tahun 2009 Pasal 23 ayat 1 dan 2 bahwa tenaga kesehatan berwenang untuk menyelenggarakan pelayanan kesehatan, dilakukan sesuai dengan bidang keahlian yang dimiliki. Sehingga tenaga kesehatan dalam melaksanakan tugasnya berkewajiban mengembangkan dan meningkatkan pengetahuan dan ketrampilan yang dimiliki tertuang juga dalam Pasal 27 ayat $2^{9}$.

Dari beberapa uraian diatas mengenai definisi rekam medis dapat disimpulkan bahwa rekam medis dapat berupa catatan yaitu tulisan yang dibuat oleh dokter atau dokter gigi tentang segala tindakan yang dilakukan kepada pasien dalam rangka pemberian pelayanan kesehatan dan dapat pula berupa dokumen yaitu catatan dokter atau dokter gigi dan/atau tenaga kesehatan tertentu, laporan hasil pemeriksaan penunjang, catatan operasi dan pengobatan serta rekaman baik berupa foto radiologi, gambar pencitraan (imaging) atau rekaman elektrodiagnosis yang harus dilakukan oleh tenaga kesehatan sesuai dengan bidang keahlian yang dimiliki.

b. Fungsi dan Tujuan

Fungsi rekam medis adalah sebagai dasar pemberian pelayanan dan evaluasi terapi yang berkesinambungan dan sebagai pelengkap evaluasi medis pasien, terapi dan perubahan kondisi pasien saat pasien berada dalam perawatan, keadaan gawat darurat, juga berfungsi untuk mendokumentasikan komunikasi yang terjadi antara dokter-dokter

8 Sunny Ummul Firdaus, SH.,MH. Dalam Rekam Medis Dalam Sorotan Hukum Dan etika, Cetakan 1. Surakarta LPP UNS dan UNS Press. 2008. Hal .7 - 8

9 Undang-Undang Republik Indonesia nomor 36 tahun 2009 tentang Kesehatan Dan Rumah Sakit. Penerbit:CV.Novindo Pustaka Mandiri. Halaman 12 dan 14 
yang bertanggung jawab memberikan pelayanan medis kepada pasien, sebagai alat bantu hukum bagi pasien, rumah sakit dan dokter juga sebagai data yang dapat digunakan untuk pendidikan dan penelitian.

Sedangkan tujuan pembuatan rekam medis kedokteran gigi merupakan catatan keadaan gigi dan keluhan pasien saat datang, sampai dengan kunjungan berikutnya, juga merupakan data resmi/legal untuk pertanggungjawaban dokter gigi serta menjadi sumber data untuk keperluan identifikasi jika diperlukan di pengadilan.

c. Manfaat

Rekam medis bermanfaat dalam pengobatan pasien sebagai dasar dan petunjuk untuk merencanakan dan menganalisis penyakit serta merencanakan pengobatan, perawatan atau tindakan medis yang harus diberikan kepada pasien. Manfaat dalam bidang pendidikan dan penelitian rekam medis merupakan informasi perkembangan kronologis penyakit, pelayanan medis, pengobatan dan tindakan medis, sehingga bermanfaat sebagai bahan informasi bagi perkembangan pengajaran dan penelitian dibidang profesi kedokteran dan kedokteran gigi. Disamping itu juga bermanfaat menyelesaikan masalah hukum disiplin dan etik ${ }^{10}$.

Bidang kedokteran gigi mempunyai banyak bagian ilmu yang dapat bermanfaat mendukung pelayanan dan informasi kesehatan dibidang gigi dan setiap bagiannya mempunyai karakter tersendiri yang membedakan jenis perawatannya antara lain Dental Public Health, Endodontic, Oral and Maxillofacial Pathology, Oral and Maxillofacial Radiology, Oral and Maxillofacial Surgery, Orthodontics and Dentofacial Orthopaedics, Periodontics, Pediatric, Prosthodontics, Dental anesthesiology, Special needs dentistry, Oral Biology, Forensic odontology / Kedokteran gigi forensik, Geriatric dentistry, Veterinary dentistry dan Aviation dentistry.

Ini semua dapat memudahkan identifikasi apabila diperlukan. Karena untuk melakukan penyidikan dalam memperoleh data-data ante dan post mortem semua aplikasi dari disiplin ilmu kedokteran gigi yang terkait menentukan otentitas dan identitas korban maupun pelaku demi kepentingan hukum dalam suatu proses peradilan untuk menegakkan kebenaran ${ }^{11}$.

Melihat manfaat rekam medis yang memiliki nilai-nilai administratif, legal, finansial, riset serta dokumentatif dan lain-lain, maka rekam medis tersebut merupakan rahasia kedokteran yang harus dirahasiakan terhadap pihak ketiga. Pembukaan isi rekam medis yang melanggar hukum dapat menyebabkan tenaga kesehatan yang bersangkutan dikenakan sanksi pidana, perdata maupun administratif.

d. Aspek Hukum

Rekam medis perlu dipahami dari aspek hukumnya secara benar oleh semua pihak, baik manager, profesional maupun pasien karena berisi hal-hal penting tentang :

1. Kepemilikan rekam medis

2. Isi Data Rekam Medis

3. Pemanfaatan data/isi rekam medis

4. Aspek Medikolegal Rakam Medis.

10 ibid 11.hal 4-6

11 Djohansyah Lukman.Drg. Buku Ajar Ilmu Kedokteran Gigi Forensik. Jilid 2. Hal .1-2 .@ 2006. CV. Sagung Seto. Cetakan I 
Aspek legal terpenting rekam medis yaitu melakukan audit medis dimana penggunaan informasi pasien terkait dengan kewajiban menyimpan rahasia kedokteran. Salah satu manfaat dari rekam medis menurut Permenkes Republik Indonesia No.269/Menkes/Per/III 2008 tentang rekam medis adalah untuk kepentingan penelitian, pendidikan dan audit medis sepanjang tidak menyebutkan identitas pasien.

Seluruh peraturan penggunaan rekam medis telah banyak ditetapkan oleh Pemerintah dalam bentuk Undang-undang maupun Permenkes juga Peraturan Pemerintah [PP] seperti yang dijabarkan diatas yaitu Undang-undang Nomor 23/1992 tentang Kesehatan, UU 29/2004 - Praktik Kedoteran, Undang-undang Hukum Pidana Pasal 322, PP No 10 tahun 1966 tentang wajib Simpan Rahasia Kedokteran, PP Nomor 32/1996 tentang TENAGA KESEHATAN, Permenkes Nomor 749a tahun 1998 tentang manfaat Rekam Medis serta yang berkaitan dengan forensik terdapat dalam KUHAP Pasal 170 ,Ayat 1 dan 2, dan kita sebagai tenaga kesehatan wajib untuk mematuhi dan dan menjalankan ${ }^{12}$.

Pada Permenkes RI nomor 269/Menkes/Per/III/2008 tentang Rekam Medis disebutkan bahwa salah satu manfaat dari Rekam Medis adalah untuk kepentingan penelitian, pendidikan dan audit medis sepanjang tidak menyebutkan identitas pasien ${ }^{13}$.

Antisipasi terhadap hal-hal tersebut yang paling utama, sederhana, dan dapat segera dilaksanakan adalah dengan cara membenahi atau membuat Rekam Medis Gigi (Dental Record) yang baik, lengkap, seragam, serta mudah dimengerti, baik oleh kalangan medis, paramedis, penegak hukum, maupun orang awam, dengan memakai standar yang berlaku universal (nasional dan internasional). Dengan perkembangan ilmu pengetahuan dan teknologi, data gigi selain dibuat secara manual pada kartu pasien dapat juga dibuat secara digital (pada komputer) dengan biaya yang secara ekonomis terjangkau.

\section{B. REKAM MEDIS ODONTOGRAM}

Rekam medis odontogram merupakan salah satu bagian dari rekam medis yaitu catatan yang berisi informasi tentang gigi seseorang yang merupakan salah satu sarana identifikasi gigi geligi yang dapat dipercaya, khususnya bila rekaman data gigi semasa hidup pernah dibuat dan disimpan secara baik dan benar. Karena gigi merupakan bagian terkeras pada tubuh manusia, yang mempunyai komposisi bahan organik dengan jumlah kadar air yang sedikit. Gigi baru akan menjadi abu pada suhu 1000 F - 1200 F (538 C - 649 C), sedangkan mahkota inlay dan tambalan amalgam pada gigi menjadi abu di atas suhu lebih $1600 \mathrm{~F}$ (871 C).

Menurut Alphonsus Quendangen dan kawan-kawan, Identifikasi personal sering merupakan suatu masalah dalam kasus pidana maupun perdata. Menentukan identitas odontogram personal dengan tepat amat penting dalam penyidikan. Apabila terjadi kekeliruan akan berakibat fatal dalam proses peradilan, karena rekam medis ini merupakan alat bukti tertulis utama, sehingga bermanfaat dalam penyelesaian masalah hukum, disiplin dan etik ${ }^{14}$.

Sifat-sifat gigi yang melekat erat pada tulang rahang, tahan terhadap proses pembusukan, tahan terhadap panas sampai 900 derajat Celcius, tahan terhadap asam, tahan terhadap abrasi maupun atrisi, nilai individualistisnya tinggi, bentuknya jelas dan mudah dikenali, menjadikan gigi sebagai salah satu bahan identifikasi. Identifikasi melalui gigi ini

12 Agus H. Rahim. ASPEK HUKUM REKAM MEDIS, [Materi kuliah MHKes Unika Soegijapranata 2009]

13 Sunny Ummul Firdaus, rekam medis dalam sorotan hukum dan etika. Hal 34

14 Alphonsus Quendangen dan kawan-kawan. Standar Nasional Rekam Medis Kedokteran Gigi Cet II. Hal 2-3 (Direktorat Jenderal Bina Pelayanan medis Departemen Kesehaatan RI tahun 2007) 
adalah proses menetapkan karakteristik unik gigi, restorasi gigi seorang individu dengan cara membandingkan data sebelum dan sesudah kematian ${ }^{15}$.

Identifikasi melalui gigi geligi dapat mengetahui ciri-ciri khas dari pada seseorang antara lain : Ras, Jenis kelamin, Umur, Kebiasaan, Pekerjaan, Golongan darah, Identifikasi wajah.

Identifikasi ini dapat dilakukan terhadap orang hidup atau mati, benda-benda mati di sekitar tempat kejadian perkara yaitu bekas pola gigitan, air liur disekitar pola gigitan dan bekas gigitan makanan tertentu, ataupun benda mati yang secara fisik dapat dianggap sebagai barang bukti antara lain, gigi palsu sebagian, gigi palsu penuh, mahkota dan jembatan, patahan gigi geligi dari korban serta patahan rahang yang lepas dari rahang atas maupun rahang bawah ${ }^{16}$.

Keuntungan gigi sebagai obyek identifikasi karena mempunyai letak yang terlindung dari otot-otot bibir dan pipi, sehingga apabila terjadi trauma akan mengenai otot-otot tersebut terlebih dahulu. Gigi geligi sukar membusuk walaupun telah dimakamkan kecuali sudah mengalami nekrotik atau gangren, sedangkan organ-organ tubuh lain bahkan tulang telah hancur tetapi gigi masih utuh dan gigi geligi manusia di dunia tidak ada yang sama dengan kemungkinan satu berbanding dua milyar, gigi juga mempunyai ciri-ciri khusus yang dapat diidentifikasi sesuai dengan pekerjaan dan kebiasaan sehari-harinya.Selain tahan panas lebih dari 649 derajat celsius juga tahan terhadap asam pekat ${ }^{17}$.

Setiap pelayanan apakah itu di rawat jalan, rawat inap dan gawat darurat dapat membuat rekam medis dengan data-data sebagai berikut ${ }^{18}$ :

a. Rekam Medis Pasien Rawat Jalan

b. Rekam Medis Pasien Rawat Inap Data pasien rawat inap.

a. Rekam Medis Pasien Gawat Darurat Data untuk pasien gawat darurat antara lain:

Khusus isi rekam medis pasien akibat bencana maka ditambahkan

1. Jenis bencana dan lokasi dimana pasien ditemukan;

2. Kategori kegawatan dan nomor pasien bencana masal dan

3. Identitas orang yang menemukan pasien;

Rekam medis untuk pelayanan dokter spesialis dan dokter gigi spesialis dapat dikembangkan sesuai kebutuhan rekam medis yang dibuat dalam pelayanan di ambulance atau pengobatan masal sama seperti rekam medis gawat darurat dan rekam medis disimpan di sarana kesehatan.

15 Rachman Ardan, Tinggi Nilai Individualistis Gigi, dalam orasi ilmiahnya yang berjudul “IImu Kedokteran Gigi sebagai Penunjang Identifikasi Forensik". Disadur tanggal 1 Juni 2010,

16 http://www.unpad.ac.id/archives/18435.

16 Ibid 14 Hal,5

17 Ibid 14. Hal.6

18 Agungrakhmawan REKAM MEDIS (PERMENKES NO: 269/MENKES/PER/III/2008) Juni 7, 2010 .http://agungrakhmawan.wordpress.com/2010/06/07/rekam-medis-permenkes-no-269menkesperiii2008/.Diambil tanggal 28 Juni 2010. 


\section{ASPEK HUKUM PERSETUJUAN TINDAK MEDIS}

Dasar Hukum

Persetujuan tindak medis dalam kaca mata hukum di Indonesia adalah suatu kewajiban hukum. Pemikiran ini didasari atas :

Secara implisit dalam amandemen Undang-Undang Dasar 1945 pasal 28 G ayat (1), Pasal 2 ayat (1) Permenkes no.585 tahun1989, Pasal 53 undang-undang nomor 23 tahun 1992 , Pasal 45 ayat (1) undang-undang no 29 tahun 2004. Peraturan-peraturan yang menjadi dasar Hukum Rekam Medis yaitu Undang-undang Nomor 29 tahun 2004 tentang Praktek kedokteran, Peraturan Menteri Kesehatan Republik Indonesia Nomor 749a/MENKES/PER/III/2008 tentang Rekam Medis, Keputusan Dirjen Pelayanan Medis Nomor 78/YANMED/RSUMDIK/YMU/I/91 tentang Penyelengggaraan Rekam Medis

\section{TUJUAN PEMBUATAN ODONTOGRAM}

Dengan mengetahui berbagai tujuan pembuatan odontogram sebagai identifikasi personal maka dengan sendirinya diwajibkan para dokter gigi untuk mengetahui, mempelajari, dan mematuhi segala ketentuan seperti yang berlaku pada Undang- Undang dan peraturan lainnya karena sanksi pidananya cukup berat secara hukum maupun secara administrasi, yang tercantum dalam pasal 45 tentang Informed Consent, pasal 46 tentang Dental Record, pasal 47 tentang kepemilikan Dental Record pasal 48 tentang Confidentiality of dental record, dan pasal 79 Ketentuan Pidana dari undang-undang dimaksud diatas.

Saat ini belum semua dokter gigi maupun perawat gigi di Indonesia melakukan pencatatan rekam medis odontogram secara benar. Masih belum ada keseragaman dalam tata cara penulisan maupun pengistilahan yang digunakan dalam pencatatan rekam medis odontogram, sehingga menimbulkan kesalahpahaman saat rekam medis tersebut dimanfaatkan dalam suatu proses hukum.

\section{E. IDENTIFIKASI}

Identifikasi dalam ilmu kedokteran gigi forensik adalah semua aplikasi dari disiplin ilmu kedokteran gigi yang terkait dalam suatu penyidikan dalam memperoleh data-data antemortem dan postmortem, dan digunakan untuk menentukan otentitas dan identitas korban maupun pelaku demi kepentingan hukum dalam suatu proses peradilan dan menegakkan kebenaran. Identifikasi melalui gigi geligi dapat dilakukan dalam terapan semua disiplin ilmu kedokteran gigi yang terkait pada penyididkan demi kepentingan umum dan peradilan serta dalam membuat surat keterangan ahli ${ }^{19}$.

Identifikasi melalui rekam medis odontogram yang dapat mendukung kedokteran gigi forensik. Dengan perkataan lain terdapat enam kriteria dari perubahan jaringan gigi akibat penggunaan gigi sesuai dengan usia. ${ }^{20}$

Pada negara-negara maju banyak terdapat dokter gigi di dalam tim penyidik dan tim identifikasi sebagai anggotanya, dengan demikian ada baiknya dokter gigi mengetahui juga identifikasi secara umum yaitu pertama dokumen yang terdapat pada busana korban seperti : KTP, SIM, kartu kredit, kartu sekolah, kartu mahasiswa, kartu karyawan serta tanda pengenal instansi. Kedua pakaian atau busana melalui bentuk, corak,

Ahli Odontologi Forensik Polri, Sindhy R. Malingkas, mengatakan Kepolisian Republik Indonesia telah menyusun Standar Operasi Prosedur (SOP) pemeriksaan kedokteran gigi

19 Ibid 14

20 Ibid 14. Hal 39, 54-61 
forensik sebagai acuan penatalaksanaan saat identifikasi korban bencana.. Hambatan di Indonesia dalam proses DVI yaitu belum adanya catatan gigi ante mortem penduduk dan belum dimiliki SOP yang baku di bidang penanganan pemeriksanaan kedokteran gigi ferensik ${ }^{21}$. Standar Operasi Prosedur diatas dapat merupakan upaya untuk dapat membuat acuan dalam rangka pembuatan rekam medis odontogram bagi seluruh dokter gigi di Indonesia dengan standar internasional.

\section{F. REKAM MEDIS SEBAGAI ALAT PEMBUKTIAN}

Rekam medis merupakan alat bukti tertulis utama, sehingga bermanfaat dalam penyelesaian masalah hukum, disiplin dan etik. Rekam medis sebagai alat pembuktian dalam perkara hukum, bisa digunakan baik yang berkaitan dengan perkara pidana maupun perdata. Rekam Pada kenyataannya tidak semua rekam medis dapat dijadikan bahan bukti dipengadilan, tetapi harus memenuhi beberapa syarat-syarat. ${ }^{22}$

\section{HASIL PENELITIAN DAN PEMBAHASAN}

\section{A. HASIL PENELITIAN}

\section{a. Gambaran umum rekam medis odontogram}

Di dalam Permenkes No. 269 tahun 2008 yang terdapat pada Pasal 3 ayat (1) dan (2) bahwa khusus untuk pasien gigi harus dibuatkan odontogram. Untuk lebih memahami catatan antemortem tersebut telah diterbitkan buku panduan serta format formulirnya yang diterbitkan oleh DEPKES tahun 2004 dengan judul STANDAR NASIONAL REKAM MEDIK KEDOKTERAN GIGI tetapi sampai saat ini buku tersebut belum banyak yang mengetahui atau mengenalnya, apalagi untuk memahaminya, sehingga dalam penulisannya belum dalam format baku nasional atau internasional tetapi menurut caranya masing-masing.

Pencatatan data gigi dan rongga mulut semasa hidup(antemortem) dilakukan terhadap anggota Polri.

\section{b. Pengolahan data}

Pengolahan data dilaksanakan melalui penyajian data dalam bentuk arsip data pribadi yang disimpan di dalam database khusus. Data odontogram yang di miliki institusi Polri yaitu Laboratorium dan Klinik Odontologi Kepolisian atau disingkat LKOK. Pusat Informasi Data Antemortem Gigi pada LKOK selama ini telah menyimpan seluruh data anggota polri terutama yang akan bertugas ke daerah konflik di dalam maupun di luar negeri dan siap digunakan bila sewaktu waktu dibutuhkan.

21 Sindhy R Malingkas, drg . sebagai pemakalah dalam seminar ilmiah bertema "Dokter Gigi Berperan Dalam Evakuasi Bencana Massal" yang diselenggarakan Persatuan Dokter Gigi Indonesia (PDGI) Cabang Padang di Hotel Pangeran Beach Padang, Padang, Sabtu.29/5/2010 (Antara/FINROLL News). http://news.id.finroll.com/nasional/kesehatan/272559-polri-susun-sop-pemeriksaan-kedokteran-gigiforensik.html [280610]. Disadur pada tanggal 25 Juni 2004

22 Akasah. Rekam Medis Sebagai Bahan Pembuktian Dalam Perkara hukum . http://akasahmanajemen.blogspot.com/2009/06/rekam-medis-sebagai-bahan-pembuktian.html. Sabtu, 27 Juni 2009 


\section{B. PEMBAHASAN}

Rekam medis odontogram merupakan berkas yang berisi catatan dan dokumen antara lain tentang identitas pasien, hasil pemeriksaan, pengobatan yang telah diberikan, serta tindakan dan pelayanan lain yang telah diberikan kepada pasien disertai foto, radiologi, gambar pencitraan (imaging). dan rekaman elektro diagnostik yang dapat dibuat secara manual atau digital.

Di dalam era globalisasi dan pasar bebas dengan tingkat persaingan yang tajam diperlukan standar-standar rekam medis Odontogram yang dapat digunakan baik secara nasional maupun internasional. Dengan maraknya bencana alam dan banyaknya aksi terorisme akhir-akhir ini maka dirasakan suatu kebutuhan yang sangat mendesak akan keseragaman standar rekam medis odontogram. Kepolisian Republik Indonesia telah menyusun Standar Operasi Prosedur (SOP) pemeriksaan kedokteran gigi forensik sebagai acuan penatalaksanaan saat mengidentifikasikan korban bencana.

Pemanfaatan rekam medis elektronik sebagai sarana pembuatan dan pengiriman informasi medis adalah merupakan upaya yang dapat mempercepat dan mempertajam bergeraknya informasi medis untuk kepentingan ketepatan tindakan medis.

\section{KESIMPULAN DAN SARAN}

\section{A. Kesimpulan}

a. Rekam medis odontogram sangat diperlukan sebagai alat identifikasi sesuai dengan Undang-Undang Praktek Kedokteran tahun 2004 dan Permenkes RI 269/Menkes/Per/2008. Dalam penyelenggaraan praktik kedokteran, setiap dokter dan dokter gigi wajib mengacu pada standar, pedoman dan prosedur yang berlaku sehingga masyarakat mendapat pelayanan medis secara profesional dan aman dan dapat terhindar dari masalah hukum.

b. Sebagai rekam medis, odontogram dapat digunakan sebagai alat bukti di pengadilan karena dikatagorikan sebagai alat bukti keterangan ahli yang tertuang dalam Permenkes No. 269/2008 pasal 13 menyebutkan bahwa Rekam Medis memiliki manfaat yaitu alat bukti dalam proses penegakan hukum, disiplin kedokteran dan kedokteran gigi dalam penegakan etika kedokteran dan etika kedokteran gigi.

c. Rekam medis odontogram elektrik atau digital memungkinkan akses yang simultan dari pelbagai lokasi di muka bumi, mengurangi kesalahan interpretasi data, mempercepat pembuatan keputusan, penyajian yang variatif dan membantu analisis data. Ini juga sesuai dengan Permenkes 269/Menkes/Per/2008 pada penjelasan pasal 46 ayat (3) bahwa penggunaan tehnologi informasi dimungkinkan dalam pencatatan rekam medis.

\section{B. Saran}

a. Dokter gigi diwajibkan segera membuat rekam medis odontogram melalui pelatihanpelatihan dan menerapkannya sesuai dengan manual rekam medis yang sudah ditentukan.

b. Perlu dibuat Standar Operasional Prosedur untuk keseragaman dalam penggunaan rekam medis odontogram bagi seluruh dokter gigi di Indonesia dan disosilisasikan secara merata dengan pengawasan yang ketat.

c. Perlu pembinaan untuk meningkatkan kemampuan dalam pelaksanaan identifikasi gigi dan mulut serta pengolahan data odontogram perlu adanya database atau penyimpanan yang baik, mengingat banyaknya kejadian-kejadian seperti bencana alam, kecelakaan ataupun korban pengeboman oleh teroris. 
d. Perlu melaksanakan kegiatan latihan ketrampilan di bidang Kedokteran Gigi untuk proses identifikasi bagi para petugas kesehatan maupun dokter giginya yang telah dilaksanakan pada instansi masing-masing dengan membuat data odontogram secara manual hendaknya ditingkatkan dengan tehnologi digital maupun secara eletronik untuk meningkatkan kemampuan tehnologi agar sebanding dengan negara maju.

e. Perlu dibuat peraturan rekam medis odontogram yang tercatat atau tertulis maupun elektronik agar dapat mempertegas kekuatan hukumnya sama atau berbeda.

f. Perlu melaksanakan kegiatan penelitian dan pengembangan tentang ilmu kedokteran gigi khususnya odontogram di dalam maupun di luar negeri, sehingga negara kita lebih banyak lagi memiliki tenaga ahli di bidang odontogram.

g. Perlu dimasukan dalam kurikulum Fakultas Kedokteran Gigi di semua Universitas secara serentak.

\section{DAFTAR PUSTAKA}

Agungrakhmawan REKAM MEDIS (PERMENKES Nomor: 269/MENKES/ PER/III/2008)Juni,7,2010, http://agungrakhmawan.wordpress.com/2010/06/07/rekam-medis-permenkes-no269menkes-periii2008/ Diambil tanggal 28 Juni 2010.

Agus H Rahim. ASPEK HUKUM REKAM MEDIS [Materi kuliah MHKes Unika Sugijapranata 2009]

Akasah. Rekam Medis Sebagai Bahan Pembuktian Dalam Perkara hukum . http://akasahmanajemen.blogspot.com/2009/06/rekam-medis-sebagai-bahanpembuktian.html. Sabtu, 27 Juni 2009

Alphonsus Quendangen .Dan kawan-kawan. Standar Nasional Rekam Medis Kedokteran Gigi Cet II. Hal 2-3 (Direktorat Jenderal Bina Pelayanan medis Departemen Kesehaatan RI tahun 2007)

A. Sonny Keraf \& Mikhael Dua, 2001, Ilmu Pengetahuan (Sebuah Tinjauan Filosofis), Kanisius, Yogyakarta, hal. 68.

Budi Sampurna. Ketepatan Lebih Tinggi, Namun Perlu Waktu Lebih Lama.http://www.suarapembaruan.com/News/2005/11/12/Utama/uto3.htm. disadur tanggal 1 Juli 2010

Djohansyah Lukman. Buku Ajar Ilmu Kedokteran Gigi Forensik . Jilid 2. Hal .1-2 . @ 2006. CV. Sagung Seto. Cetakan 1.

Fred N. Kerlmger, 1992, Asas-asas Penelitian Behavioral diterjemahkan oleh: Landung R. Simatupang, Gadjah Mada University Press, Yogyakarta, hal. 18.

Johnny Ibrahim, 2006, Teori dan Metodologi Penelitian Hukum Normatif, Bayumedia Publishmg, Surabaya, hal. 25-26.

Moh. Nazir, Metode Penelitian, Ghalia Indonesia, Jakarta, 1985, hlm. 63, 72, 405, 406 \& 427; Lihat pula Human Hadikusuma, 1995, Metode Pembuatan Kertas Kerja atau Skripsi Ilmu Hukum, Mandar Maju, Bandung, hal. 98

Rachman Ardan, Tinggi Nilai Individualistis Gigi. Dalam orasi ilmiahnya yang berjudul "Ilmu Kedokteran Gigi sebagai Penunjang Identifikasi Forensik". 11 Desember 2009

http://www.unpad.ac.id/archives/18435., Disadur tanggal 1 Juni 2010

Shindhy R. Malingkas, Dental Charting (In Use to DVI Interpol Post Mortem form) BIDDOKPOL PUSDOKKES POLRI 
Sindhy R Malingkas, sebagai pemakalah dalam seminar ilmiah bertema "Dokter Gigi Berperan Dalam Evakuasi Bencana Massal" yang diselenggarakan Persatuan Dokter Gigi Indonesia (PDGI) Cabang Padang di Hotel Pangeran Beach Padang, Padang, Sabtu.29/5/2010 (Antara/FINROLL News). http://news.id.finroll.com/nasional/kesehatan/272559-polri-susunsop-pemeriksaan-kedokteran-gigi-forensik.html [280610]. Disadur pada tanggal 25 Juni 2004

Soetandyo Wignjosoebroto, 2002, Hukum (Paradigma Metode dan Dinamika Masalahnya) Editor: Ifdhal Kasim et.aL, Elsam dan Huma, Jakarta, hal. 147-160.

Soerjono Soekanto \& Sn Mamudji, 2001, Penelitian Hukum Normatif (Suatu Tinjauan Singkat), Rajawaii Pers, Jakarta, hal. 13-14.

Sunny Ummul Firdaus, SH.,MH. Dalam Rekam Medis Dalam Sorotan Hukum Dan etika, Cetakan 1. Surakarta LPP UNS dan UNS Press. 2008. Hal .7-8

Taliziduhu Ndraha, Research, 1985, (Teori Metodologi Administrasi), Bina Aksara, Jakarta, hal. 6061

Undang-Undang Republik Indonesia nomor 36 tahun 2009 tentang Kesehatan Dan Rumah Sakit. Penerbit:CV.Novindo Pustaka Mandiri. Halaman 12 dan 14

Wila.Chandra. Supriadi. Guru Besar Hukum Kesehatan Unika Parahyangan Bandung. Rekam Medis Menurut Permenkes no.269/2008 \& UU no.29/2004) Senin, 18 Mei 2009. http://rekammedisugmo8.blogspot.com/2009/05/rekam-medis-menurut-permenkesno.html. disadur tanggal 23 Juni 2010

\section{Lampiran}

\section{ODONTOGRAM DIPERGUNAKAN PADA SAAT INI}

Adalah keadaan gigi geligi di dalam suatu diagram yg menggambarkan keadaan setiap gigi secara terperinci dan merupakan kelengkapan dental record dimana pada tahap awal harus dilakukan pemeriksaan dan pencatatan seluruh keadaan gigi dan mulut pasien. Adapun manfaat dari odontogram :

1. Sebagai data antemortem untuk identifikasi.

2. Sebagai alat bukti yang sah menurut Hukum

3. Merupakan hak pasien untuk mendapatkan kejelasan tentang status dirinya sendiri maupun keluarganya.

\section{PENULISAN ODONTOGRAM}

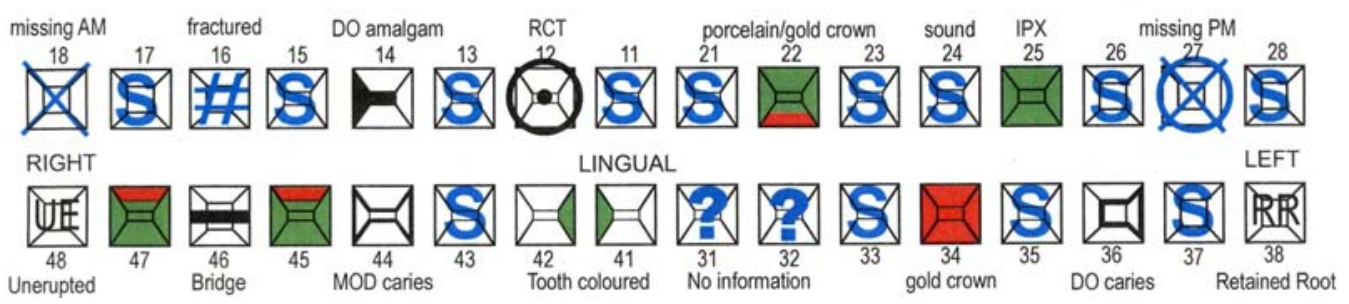


1. Standar Interpol.

2. Berlaku universal.

3. Lebih sederhana dan lebih praktis.
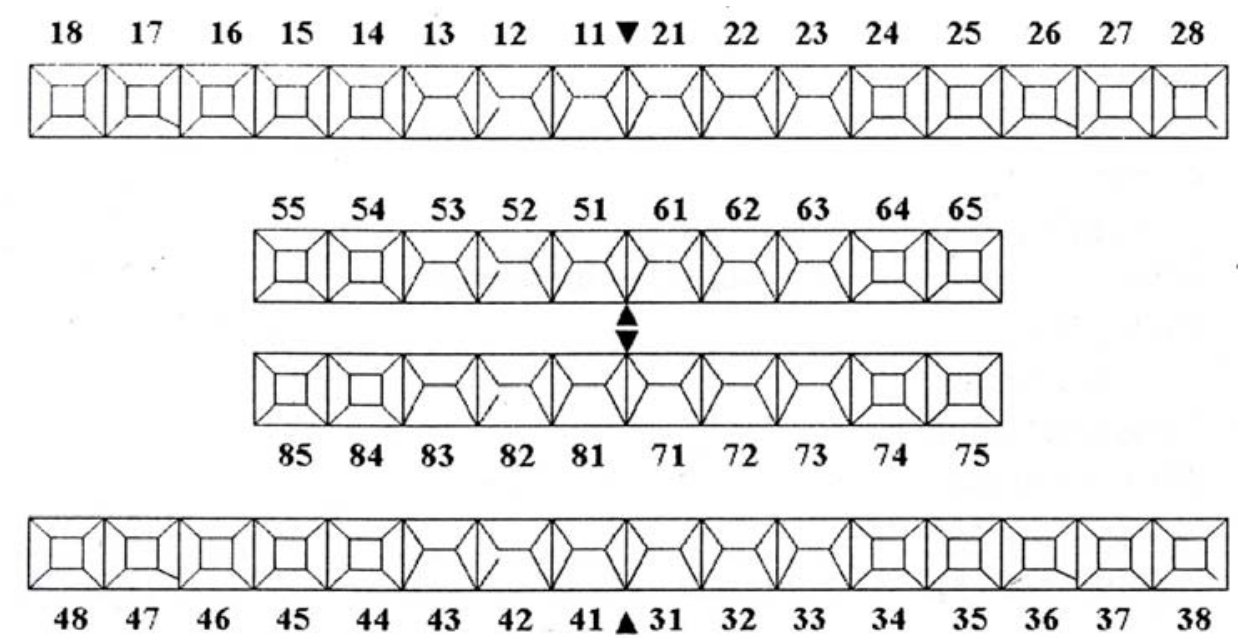

1. Seluruh Penulisan notasi gigi memakai format FDI.

2. Setiap gigi harus ditulis notasinya.

3. Charting dimulai dari rahang atas kanan dari gigi 18 dan di akhiri sampai gigi 48

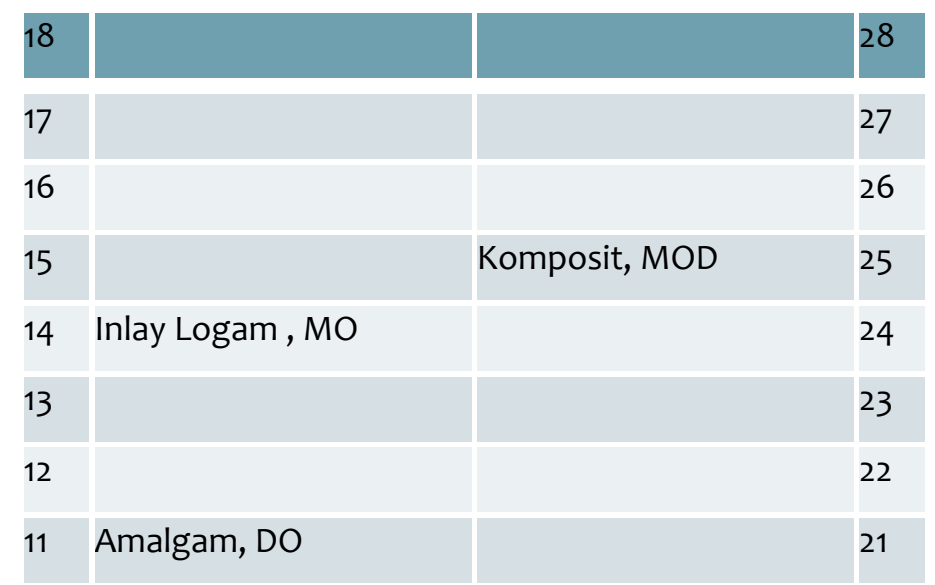

Permukaan Gigi

Dituliskan dengan Inisial awal memakai huruf besar :
a. $M=$ Mesial
b. $\mathrm{D}=$ Distal
c. V = Vestibular (biasa juga disebut Bukal, Labial dan Fasial)
d. $L=$ Lingual
e. $\mathrm{O}=$ Oklusal 

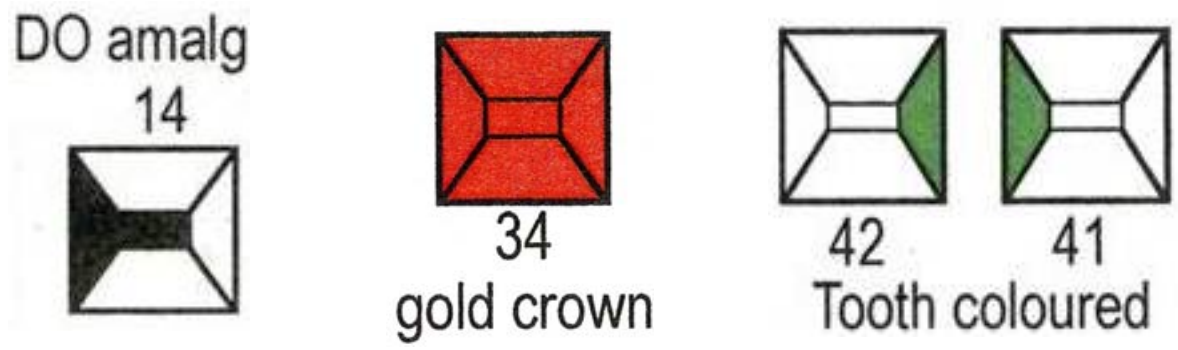

Material Restorasi

Warna digunakan untuk melambangkan:

a. Amalgam dan Inlay logam (selain logam mulia) : Hitam

b. Emas (logam mulia/berharga lainnya): Merah

c. Tambalan sewarna gigi (termasuk komposit, glass ionomer, porcelain) : Hijau

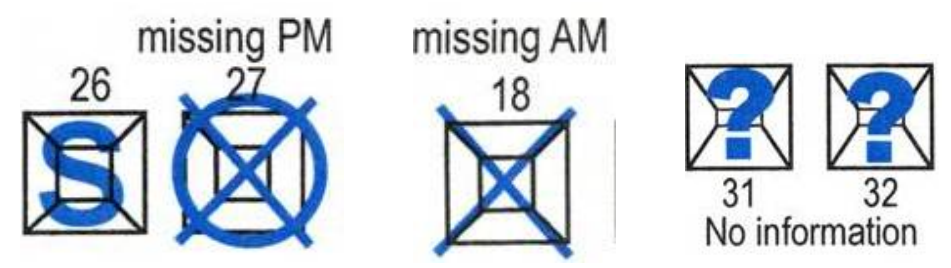

Keadaan Gigi:

Sound : Tidak ada karies atau restorasi, diberi tanda "S" pada odontogram

Missing:

a. Missing Ante Mortem - diberi tanda "X" pada odontogram.

b. Missing Post Mortem - diberi tanda " $X$ " dan dilingkari pada odontogram.

C. Kehilangan bagian rahang ditulis pada teks box.

Tidak ada informasi: diberi tanda "?" pada odontogram dan ditulis NON pada teks box (form AM)

\section{IPX}
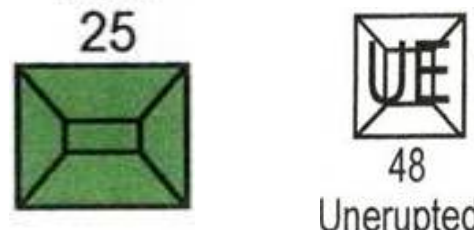

Unerupted Retained Root

Dental Implan : Tuliskan "IPX" diatas odontogram (dengan restorasi mahkotanya)

Gigi belum tumbuh (UnErupted Tooth) : : Tuliskan “UE” pada Odontogram.

Sisa Akar (Retained Root)

:Tuliskan “RR” pada odontogram. 


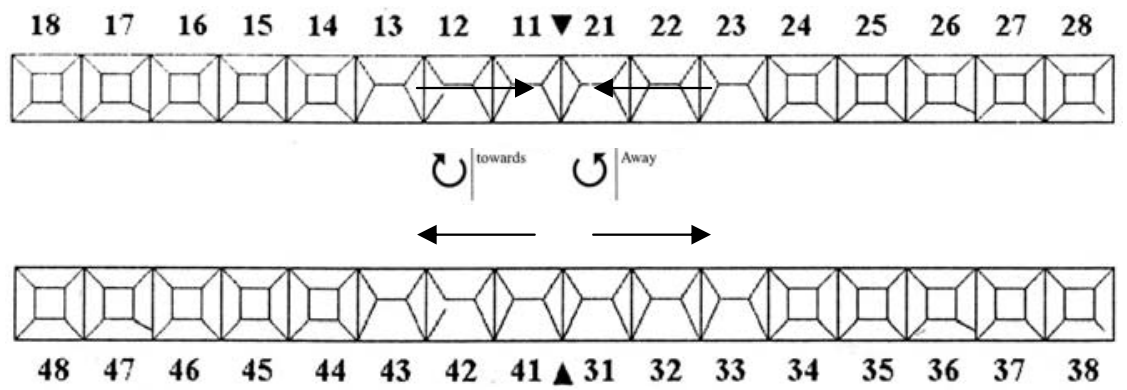

$\begin{array}{ll}\text { Penutupan Jarak (Space Closure) } & : \text { Gunakan anak panah } \\ \text { Diastema (Space Opened) } & : \text { Gunakan anak panah } \\ \text { Rotasi Gigi } & : \text { Gunakan kurva panah }\end{array}$

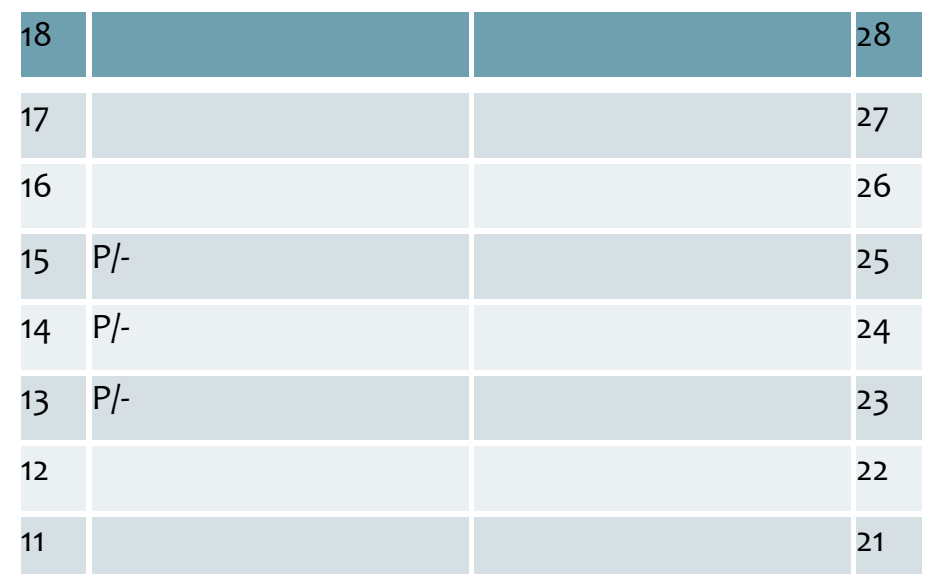

Gigi Tiruan :

- Full Maxillary Denture F/-

- Full Mandibular Denture $\quad$-/F

- Partial Maxillary Denture P/-

- Partial Mandibular Denture $\quad$-/P

Keterangan Lainnya:

Keterangan Lainnya : berikan keterangan lebih lanjut tentang oklusi, status periodontal dan kelainan lainnya. 